\title{
The views of Aotearoa/New Zealand adults over 60 years regarding the End of Life Choice Act 2019
}

\author{
Rosemary Frey $^{1}$ (D) Deborah Balmer ${ }^{1}$
}

Accepted: 18 July 2021 / Published online: 5 August 2021

(c) The Author(s), under exclusive licence to Springer Science+Business Media, LLC, part of Springer Nature 2021

\begin{abstract}
This study described the views of older New Zealand adults toward assisted dying and specifically the End of Life Choice Act (2019), an Act making assisted dying legal. An anonymous postal and online survey of 636 adults 60 years and older was conducted. The majority of respondents did not support legalization (85.7\%), while $8.8 \%$ were in favor (5.5\% did not specify a view). Weighted binary logistic regression indicated that the odds of support for legalization were lower in those respondents with a religious affiliation $(\mathrm{OR}=.020$, S.E. $=0.60, p=.00)$, and there were 2.66 times greater odds in those identifying as male (S.E. $=0.34, p=.005)$. On the other hand, those respondents under 65 years had increased odds of supporting legalization $(\mathrm{OR}=1.89$, S.E. $=.029, p=.045)$. Results indicate that most participants were concerned about potential abuses and coercive practices if assisted dying became legally available in New Zealand.
\end{abstract}

Keywords Assisted dying · End of Life Choice Act · Euthanasia · New Zealand · Older adults

\section{Introduction}

Euthanasia and assisted suicide are controversial and complicated social, ethical, and medical issues. In the UK (Jaye et al., 2021), many assisted suicide bills have been advanced to Parliament, with none being successful. In some jurisdictions, euthanasia has been legalized, including the Netherlands and Belgium in 2002, Luxembourg in 2009, Colombia in 2015, and Canada in 2016. Assisted suicide is more widely available than euthanasia. Among the locations where people can choose to end their lives in this manner are Switzerland and several US states, including

Rosemary Frey

r.frey@auckland.ac.nz

1 School of Nursing, Faculty of Medical and Health Sciences, University of Auckland, 85 Park Road, Grafton, Auckland, New Zealand 
California, Colorado, Hawaii, New Jersey, Oregon, Washington State, Vermont, and the District of Columbia. Laws permitting assisted suicide came into effect in the Australian state of Victoria in 2019 (Luzon, 2019).

The terminology related to euthanasia and assisted suicide has yet to be internationally standardized. Euthanasia and assisted suicide (EAS) refer to two different practices (Dixon, 1998; NHS, 2020). According to the European Association for Palliative Care (EAPC), euthanasia is defined as "the process by which a medical professional actively ends a patient's life by some medical means in response to a patient's voluntary and competent request" (Radbruch et al., 2016, p. 108). In contrast, assisted suicide refers to "a person intentionally helping another person to terminate his or her life at that person's voluntary and competent request" (Radbruch et al., 2016 p. 108).

In Aotearoa, New Zealand, "assisted dying" is a blanket term for assisted suicide and voluntary euthanasia. The End of Life Choices Act was first entered into a Parliament members' bill ballot in October 2015 (ACT, 2015). After a lengthy process, it passed its third and final reading in November 2019 (Cooke, 2019). On November 16, 2019, the End of Life Choice (EOLC) Act (2019) was given Royal Assent. ${ }^{1}$ At the 2020 General Election, New Zealanders voted in a binding referendum on whether the End of Life Choice Act 2019 (the Act) should come into force. A majority of voters supported the Act (MOH, N.Z., 2021). Research by Crothers (2020) synthesizing nationwide poll results before the General Election found that the majority of respondents across all aged groups supported the Act (77.7\%), with the highest level of support among 31-45-year-olds (81.3\%).

Under the Act, New Zealanders eighteen years or older, with a prognosis of death in less than six months, have the right to: have medication administered by a medical practitioner or nurse practitioner (s 3(a)), or self-administer medication (s 3 (b)) to "relieve the person's suffering by hastening death" (ss 3(a), (b)). ${ }^{2}$ Following the 2020 Referendum, the Act comes into effect in November 2021.

Vulnerability. A key issue in the debate is the literature suggesting that socially marginalized populations may potentially be at risk of overutilization of EAS if both were to become legalized (Lamers \& Williams, 2016). Yet, the attitudes of vulnerable populations toward EAS have not been widely studied. Vulnerable groups can include but are not limited to older adults, the mentally ill, the physically disabled, persons in low socioeconomic brackets, refugees, and drug and alcohol abusers

\footnotetext{
1 For a detailed description see: New Zealand Parliament (2016) How a bill becomes a law. Wellington, NZ: NZ Parliament.

2 The Act's purpose, pursuant to s 2, is:
}

(a) to give persons who have a terminal illness and who meet certain criteria the option of lawfully requesting medical assistance to end their lives; and

(b) to establish a lawful process for assisting eligible persons who exercise that option.

Pursuant to s 3, assisted dying, in relation to a person, means-

(a) the administration by an attending medical practitioner or an attending nurse practitioner of medication to the person to relieve the person's suffering by hastening death; or

(b) the self-administration by the person of medication to relieve their suffering by hastening death 
(Jecker, 1991; Morrow, 1997). The opinions of these marginalized and/or potentially at-risk groups toward assisted death are important precisely because they are the people for whom it has been hypothesized that assisted dying could be seen as obligatory rather than a choice (Malpas et al., 2014). Indeed, research by Koenig et al. (1996), conducted with elderly outpatients and their families in the USA, found that patients who would be considered vulnerable to the misuse of physician-assisted suicide (e.g., elderly persons, women, minority individuals, and poor, uneducated, and persons with dementia) were those persons who were most opposed to it. Lord Sumption of the High Court of England and Wales observed in Nicklinson (10a), "the legalization of assisted suicide would be followed by its progressive normalization, at any rate among the very old or very ill. In a world where suicide was regarded as just another optional end-of-life choice, the pressures ... are likely to become more powerful." The New Zealand Disability Rights Commissioner (Tesoriero, 2019) highlights the issue of coercion, which "can come not just from individuals but from broader messages in society at large, be that advertising, be that the ablest world we live in, and attitudes around disability." In four nations where euthanasia has been legalized, the original criteria at first legalization have been broadened (Gale \& Barak, 2020). Others in Canada lament the insufficient attention given to making assisted dying and other palliative care services accessible to vulnerable populations (Wright \& Shaw, 2019). Thus, those whose lives are most likely to be affected by the Act may be isolated, marginalized, and politically invisible.

Older age is often accompanied by multi-morbidity (Aarts et al., 2015). Also, as people age, they tend to rate their health more poorly (Gunzelmann et al., 2006) and are more likely to receive institutional care (Broad et al., 2013). Thus, living longer in old age could more frequently be accompanied by complex conditions requiring special care (Boyd et al., 2009; Broad et al., 2013). Furthermore, in industrialized societies, ageism is entrenched in social institutions (Lamers \& Williams, 2016). There is growing international literature on the paternalistic and ageist ways that older adults are treated within health care systems (Dobrowolska et al., 2019; Inouye, 2021; Wyman et al., 2018). Increased health risks, environmental pressures, and the economic stresses associated with advanced age and the aging process have meant that older persons are a "vulnerable population" (Kane \& Kane, 2005). Studies from the USA, Netherlands, and Belgium, where voluntary assisted dying is legal, show that most patients who access voluntary assisted dying are over 65 (Gomes et al., 2011). Studies highlight that loss of autonomy, dignity, and engagement in enjoyable activities are the predominant motivators for people choosing voluntary assisted dying (Downar et al., 2017). A New Zealand study further found that healthy older adults who supported euthanasia or assisted dying nevertheless had concerns about possible future impairment and dependency on others, as well as fears around becoming a burden (Jaye et al., 2021). Considering the implications of euthanasia or assisted dying for this population in particular and the zeitgeist any law change would introduce, this represents an area that needs empirical investigation.

Of course, older adults are not a homogeneous group, and many factors may influence their attitudes concerning euthanasia and assisted suicide (EAS). Concerns have also been raised that women, as a marginalized group, are at risk of requesting assisted dying due to gendered circumstances rather than personal choice 
(Hammond-Thrasher, 2020). Previous research supports some gender differences in the endorsement or use of EAS. Men favor physician-assisted dying when alive (Espino et al., 2010), and more women have died by physician-assisted dying (Steck et al., 2014, 2016). The reluctance of females to seek life-prolonging medical interventions has been ascribed to older women's wish not to be a burden on others (Arber et al., 2008). Therefore, this variable was also investigated.

Research supports the view that religion and spirituality are essential resources for older adults when facing death and further is associated with patients' medical decision-making (Karches et al., 2012; Puchalski, 2010). Concerning EAS, Bulmer et al. (2017), in a US study of 1598 participants ranging from 18 to 96 years, reported that higher levels of religiosity (how religious they consider themselves) uniquely predicted lower levels of support for physician-assisted suicide. Earlier research has also shown similar results for both religious affiliation and religious commitment in uni- and multivariate analyses for support of euthanasia or physician-assisted suicide (Burdette et al., 2005; Carter et al., 2007; Cohen et al., 2014; Espino et al., 2010; Güell et al., 2015; Televantos et al., 2013). Fortuin et al. (2020) propose that for older adults, who grew up in a more traditional society, religion may still hold existential authority.

Older people may qualify as vulnerable in the context of the Act, and their views are vital. Although all individuals 60 years of age and older are not at risk per se (Curran, 1997), many experience physical, sensory, and cognitive decline as they age. These characteristics, combined with the cost of care, may render them relatively at risk. The study sought to illuminate older people's views of the End of Life Choice (EOLC) Act (the Act) in New Zealand and other life-ending practices, namely assisted dying.

\section{Methodology}

An anonymous postal and online survey of adults 60 years and older was conducted. The questionnaire was adapted from international public surveys of attitudes toward proposed euthanasia and assisted dying legislation (Malpas et al., 2014) and consultation with clinical and legal experts. Survey responses were collected from July to November 2020 before the New Zealand vote on the referendum.

Questionnaire-The questionnaire consisted of two sections. Section One requested demographic information (e.g., gender, age, ethnicity, occupation). In addition, one question identifying religious affiliation and two items on the strength of religious belief and spiritual belief on a five-point Likert scale (1 extremely to 5 not at all) adapted from Frommelt (1991) were included. Finally, two open-ended questions requested the respondents' definition of assisted dying and their understanding of the distinction between assisted dying and suicide.

Drawing on Kouwenhoven (2012) in Section Two, respondents were asked about their understanding of the Act's applicability, presented in four different vignettes in a multiple response format. Definitions of assisted dying "a practice whereby a doctor provides the medication to enable a competent patient to take their own life if they have made explicit and repeated requests to die' and voluntary euthanasia 
"a practice whereby a doctor intentionally ends a competent patient's life after they have made explicit and repeated requests to die" were presented before each vignette. A filter item identifying support/non-support of the Act was included. One item requested whether the respondent's choice was influenced by the COVID-19 pandemic (yes/no). Two multiple-choice items followed, developed in consultation with clinical and legal researchers, to identify the reason for support/non-support. Finally, an item requested whether the respondent had been a carer of another person at the end of life (yes/no) (Table 1).

\section{Sample and Sampling}

Organizations with a predominantly older adult membership were purposively recruited for this study. These organizations included media, health, and social service, and registered non-profit groups. The organizations either had no official position or represented a diversity of opinion on the Act's passage based on published statements. None of the participating organizations had a stated religious affiliation. To protect their members' rights to privacy and in line with local ethics requirements, participating organizations sent out the invitation and participant information sheet to their membership. As the organizations' membership lists were private and not accessible to the researchers, there was no possibility of drawing a probability sample. Purposive and convenience sampling was by necessity utilized to recruit participants. A response rate calculation was not possible based on the sampling methods (including privacy requirements related to organization membership list numbers).

\section{Postal Questionnaire}

Interested members contacted researchers directly (e.g., by phone or email) to request a copy of the questionnaire, a consent form, and a self-addressed envelope. Participants posted the survey and consent form back to the researchers.

\section{Online Questionnaire}

Participants to the online survey were provided with a link to a page with further information about the study. The researcher's contact details were provided if they wished to ask further questions. Those who continued to the questionnaire were directed to a consent page to complete before being allowed to proceed.

\section{Data Analysis}

Quantitative data were coded into SPSS (vers. 25). Both descriptive (frequencies, mean, standard deviation) and inferential statistics (Chi-square, t-tests, binary logistic regression) were employed. The level of statistical significance was set at $p<0.05$. Data were weighted according to the sex/age $(60-64 / 65+) /$ religious affiliation (yes/no) structure of the New Zealand population using data from the 2018 
Table 1 Demograhic characteristics of participants $(n=636)$

\begin{tabular}{|c|c|c|}
\hline Variable & Frequency & Percent \\
\hline \multicolumn{3}{|l|}{ Gender } \\
\hline Male & 228 & 35.8 \\
\hline Female & 404 & 63.5 \\
\hline Other & 3 & .5 \\
\hline Unknown & 1 & .2 \\
\hline \multicolumn{3}{|l|}{ Age } \\
\hline $60-70$ & 305 & 48.0 \\
\hline $71-81$ & 273 & 42.9 \\
\hline $82+$ & 58 & 9.1 \\
\hline \multicolumn{3}{|l|}{ Ethnicity } \\
\hline NZ European & 515 & 81.0 \\
\hline Maori & 11 & 1.7 \\
\hline Pacific & 3 & .5 \\
\hline Asian (Chinese, Korean, Other Asian) & 9 & 1.4 \\
\hline Southeast Asian (Indian, Pakistani, Sri Lankan) & 9 & 1.4 \\
\hline Middle Eastern, Latin American, South African & 2 & .3 \\
\hline Other European (e.g., English, Australian, South African) & 66 & 10.4 \\
\hline Other ethnicity & 19 & 3.0 \\
\hline Unknown & 2 & .3 \\
\hline \multicolumn{3}{|l|}{ Occupation } \\
\hline Retired & 342 & 53.8 \\
\hline $\begin{array}{l}\text { Professional or Govt. Official (doctor, physicist, civil engineer, teacher, nurse, } \\
\text { etc.) }\end{array}$ & 80 & 12.6 \\
\hline Business owner or self-employed & 42 & 6.6 \\
\hline Clerical, service or sales & 18 & 2.8 \\
\hline Full-time home-maker & 18 & 2.8 \\
\hline Business manager or executive & 11 & 1.7 \\
\hline Social welfare beneficiary or unemployed & 10 & 1.6 \\
\hline Other skilled worker & 8 & 1.3 \\
\hline General manager or specialized manager & 7 & 1.1 \\
\hline Farm owner or manager & 7 & 1.1 \\
\hline Police or other service worker & 1 & .2 \\
\hline Skilled tradesperson (e.g., builder, electrician, etc.) & 1 & .2 \\
\hline Laborer, manual farm, or domestic worker & 1 & .2 \\
\hline Student & 1 & .2 \\
\hline Other occupation & 87 & 13.7 \\
\hline \multicolumn{3}{|l|}{ Do you work in healthcare? } \\
\hline Yes & 87 & 13.7 \\
\hline No & 540 & 84.9 \\
\hline Unknown & 9 & 1.4 \\
\hline \multicolumn{3}{|l|}{ What is your religious affiliation? } \\
\hline Christian & 553 & 86.9 \\
\hline Buddhist & 2 & .3 \\
\hline
\end{tabular}


Table 1 (continued)

\begin{tabular}{lrl}
\hline Variable & Frequency & Percent \\
\hline Jewish & 2 & .3 \\
Other (e.g., Mormon, universalist, catholic, etc.) & 21 & 3.3 \\
No religion & 50 & 7.9 \\
Unknown & 8 & 1.3 \\
Have you ever been involved in the care of someone else at the end of his or her life? & \\
Yes & 437 & 68.7 \\
No & 98 & 15.4 \\
Unknown & 101 & 15.9 \\
\hline
\end{tabular}

census to reduce the risk of biased estimates (Statistics New Zealand, 2018). Some item response categories were collapsed into dichotomous categories (e.g., religious affiliation/no religious affiliation; age under $65 / 65 \mathrm{yrs}$; and over) to ensure adequate cell sizes for comparative analyses. Analysis of the vignettes and open-ended questions is the subject of another article in progress.

\section{Ethical Considerations}

The study received approval from the University of Auckland Human Participants Ethics Committee (Ref 024560). Participant information was offered, as well as an opportunity to ask questions of the researcher before taking part in the study. The online survey was fully anonymized, and the information was kept private in secure and password-protected files at the University of Auckland. Consent forms were stored separately from questionnaires in the paper-based format. Participation in the study was voluntary, and all participants provided consent to participate either in written or electronic form.

\section{Results}

\section{Overview of Participants}

Responses were received from 636 eligible respondents (64\% female, $36 \%$ male, and $0.5 \%$ other), the majority of whom identified as N.Z. European $(81 \%)$ followed by other European (10\%) (Table 1). Ages ranged from 60 to 91, with an average age of 71(95\% CI 70.2-71.3). Slightly over half (53\%) reported that they were retired. Only $14 \%$ said they were working in healthcare; however, $63 \%$ reported they had accompanied someone in death. Ninety percent reported a religious affiliation (Table 1).

\section{Support Legalizing Assisted Dying}

Participants were asked, "Do you think assisted dying should be made legal in New Zealand?" The majority of respondents did not support legalization (85.7\%), while 
$8.8 \%$ were in favor (5.5\% did not specify a view). The strength of religious beliefs may have shaped this opinion. Those who did not support legalization were significantly more likely to have reported being very religious $t(570)=-8.56, p=0.000$. Most of the 569 participants who responded to the question felt that the experience of COVID-19 had not changed their opinion about legalizing assisted dying (98.9\%). One percent said it had an impact.

\section{Why?}

Respondents were asked to select the reasons for their support or opposition to legalization. For those against legalization, the top three reasons included the expectation of vulnerable groups to use the Act to save resources (95.5\%), expectations of the vulnerable to use the service ( $95.4 \%$ persons), and the belief that a doctor's role is to heal (94.4\%) (Fig. 1). The minority (56 persons/ 8.8\%) in support of legalization reported preventing pain and suffering (94.6\%) and inability to control pain by palliative care $(84.5 \%)$, and ability to still make the decision $(75.1 \%)$ as the most frequent responses (Fig. 2).

\section{Predictors of the Support for Legalizing Assisted Dying}

Weighted binary logistic regression was undertaken to assess the association between the predictors (gender, age, religious affiliation (yes/no)) and support for legalizing assisted dying. Initial Chi-square analyses of the independent variables indicated no significant relationships $(p<0.05)$. Therefore, no interaction terms were included in the final model. When the predictor variables were considered together, they significantly predicted support, $\left(x^{2}=58.57, d f=3, N=592, p<0.001\right)$. Prediction success overall was $92.1 \%$ (23.8\% for yes, $99.2 \%$ for no). Results for the final model show that the odds of support for legalization were lower in those participants with a religious affiliation $(\mathrm{AOR}=0.020,95 \% \mathrm{CI} 0.006-0.064)$, and there were increased odds in those identifying as male (AOR $=2.66,95 \%$ CI 1.35-5.24). Those participants 64 years or younger also had increased odds of supporting legalization $(\mathrm{AOR}=1.89,95 \% \mathrm{CI}(1.01-3.54)$ (Table 2$)$.

\section{Discussion}

The survey results shed some light on the complicated and emotionally charged issue of assisted dying, reflecting ordinary people's perspectives. For some New Zealanders, the consideration of assisted dying will be more than an academic exercise given the 2020 Referendum result. The majority of participants cited concern over potential abuses and coercive practices if assisted dying became legally available in New Zealand. Their concerns reflect those found in several studies (Golden 


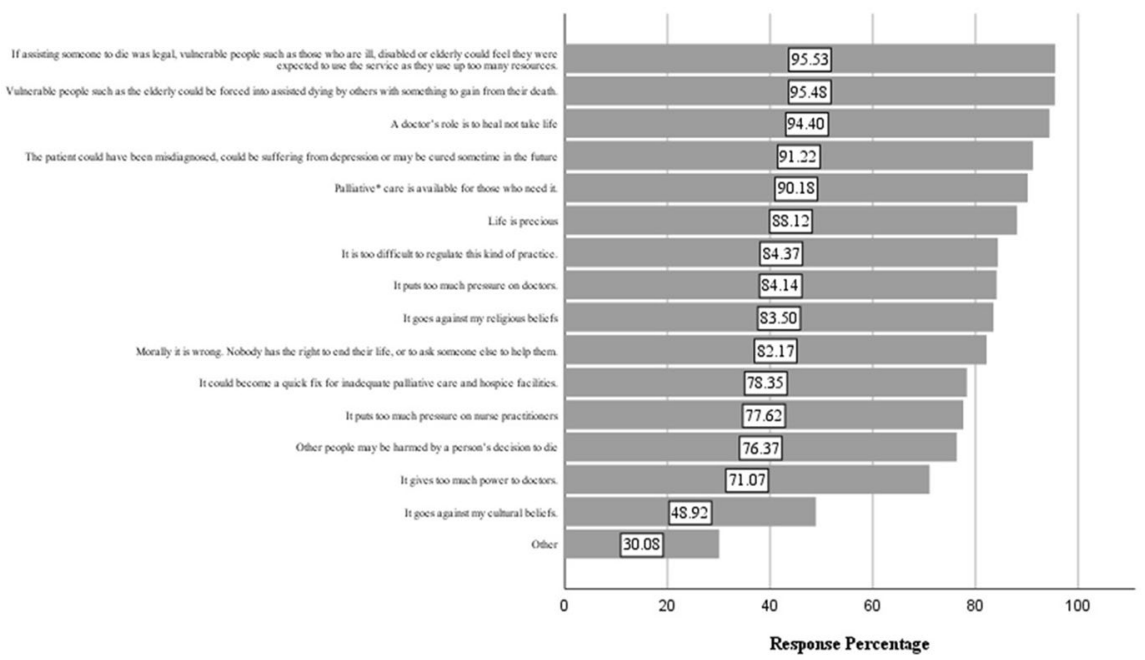

Fig. 1 Which of the following options reflect why you think assisted dying should not be available in New Zealand? (multiple response) $(N=540)$

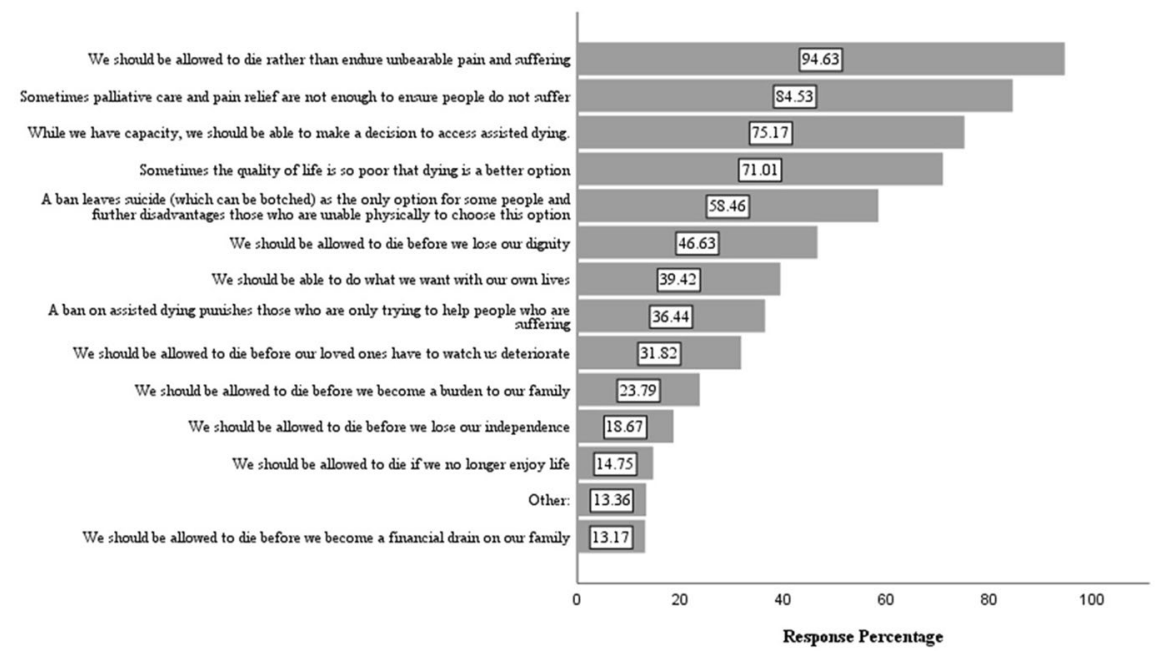

Fig. 2 Which of the following options reflect why you think assisted dying should be available in New Zealand? (multiple response) $(N=80)$ 
Table 2 Binary logistic regression showing the statistically significant predictors of support for legalizing assisted dying $(N=592)$

\begin{tabular}{llrlll}
\hline Variables & B $(\mathrm{SE})$ & Wald & Df & $p$ value & AOR (CI) \\
\hline Age $[60-64=0,65+=1]$ & $.64(.029)$ & 4.03 & 1 & $.045^{*}$ & $1.89(1.01-3.54)$ \\
Religious affiliation $[$ no $=0$, yes $=1]$ & $-3.93(0.60)$ & 42.29 & 1 & $.000^{* *}$ & $.020(.006-.064)$ \\
Gender [male $=0$, female $=1]$ & $.98(0.34)$ & 8.06 & 1 & $.005^{*}$ & $2.66(1.35-5.24)$ \\
Constant & $1.88(0.23)$ & 66.87 & 1 & $.000^{* *}$ & \\
\hline
\end{tabular}

There were no interactions among independent variables. No multicollinearity detected

*Significant at the .05 level, **significant at the .001 level

\& Zoanni, 2010), particularly where the participants were considered vulnerable (George et al., 2005; Morrow, 1997).

However, for the minority of older adults in this study supporting assisted dying, they wanted to retain control of their own lives or death and avoid suffering or burdening their families. A systematic review of the views of patients, carers, and the public on assisted dying by Hendry et al. (2013) found that the relief of unbearable suffering was a key construct in the literature. Supporters also reported assisted dying as a possible means of contributing to the quality of death by respecting the person's wishes, relieving potential suffering, and preserving dignity. A national survey by Vilpert et al. (2020) in Switzerland (where assisted suicide is legal) found that control over the end of life and the ability to maintain essential capabilities at the end of life were positively associated with support for assisted suicide.

Older adults who described themselves as affiliated with a religion were more likely to disagree with legalizing assisted dying. This finding supports previous research indicating that religious affiliation is associated with a lower wish for assisted death (Burdette et al., 2005; Steck et al., 2018). Analysis of responses of 1066 individuals in the US General Social Survey found that religiosity, belief in the afterlife and heaven, and religious denomination were significantly associated with opposition to euthanasia (Sabriseilabi \& Williams, 2020). Finally, a review of the literature by Castelli Dransart et al. (2019) reported that religious affiliation was not associated with support for euthanasia or physician-assisted suicide in Switzerland or Connecticut, and Indiana in the USA.

In line with Gendall's (2002) results, men were more likely to support assisted dying than women. In contrast, several studies have found similar levels of support of euthanasia or assisted dying by both men and women, and other studies found overall support and opposition to be highly similar according to gender (Colmar Brunton, 2008; Gendall, 2009; Horizon Research Limited, 2012; Lee et al., 2017). It may be that the lived experience of gender roles in society provides a possible explanation for the observed differences in attitude toward assisted dying. Previous research has demonstrated that men and women experience aging differently (Canham, 2009; Panek et al., 2014; Smith et al., 2007; Wehrle, 2020). These differences extend to the experience of end-of-life (Hilário, 2015). Western masculine norms requiring the portrayal of strength, autonomy, and action may in part underlie their attitudes toward assisted dying (King et al., 2020). 
Results indicated that persons under 65 years of age were more likely to support assisted dying. These results are corroborated by previous research. Using cumulative 1977-2016 General Social Survey (US) data, Attell (2020) concluded that support for euthanasia and suicide generally decreases as people age. Results by Lee et al. (2017) to the 2014/2015 New Zealand Attitudes and Values Study (NZAVS) survey similarly reported a negative relationship between support for euthanasia and age. Although supported by previous research, the results do not provide the reasons underpinning this support. One possible explanation is that these results represent a cohort effect, with younger generations holding less conservative attitudes than previous generations (Twenge et al., 2015). Future research should explore an in-depth understanding of the basis of this support.

Concern has also been raised internationally that COVID-19 pressures may impact older adults' decision to seek assisted dying. A 2020 report by Médecins Sans Frontières (Doctors without Borders) that included a survey of people's mental health in aged care facilities in Belgium found that their contemplation of euthanasia had increased. In contrast, our results found that COVID-19 was not a significant consideration in participants' decisions about assisted dying support. Future research on the impact of COVID-19 should be undertaken once the Act comes into force in 2021.

\section{Limitations}

The study utilized purposive and convenience sampling making generalizability difficult. Convenience sampling has well-known methodological shortcomings, particularly concerning bias (Etikan et al., 2016). In this study, these shortcomings have been lessened by (1) providing detailed participant demographic descriptions (see Table 1), (2) weighting the survey data based on Statistics New Zealand (2018) census data (to make statistics calculated from the data more representative of the population) and (3) ensuring that the participants who were recruited were theoretically relevant to the study (i.e., purposively selected organizations whose membership were 60 years or older), so that selection was not based on convenience alone (Waterfield, 2018). A second limitation concerned the ethnic makeup of the sample, which underrepresented the primary New Zealand ethnic minority groups (Māori, Asian, and Pacific people) as identified in the 2018 census (European 70.2\%, Māori 16.5\%, Asian 15.1\%, and Pacific people 8.1\%) (Statistics N.Z., 2018). However, previous New Zealand research has found lower support for EAS among ethnic minority groups (Young et al., 2019). In addition to the above, and even though this study identifies attitudes about assisted dying by religion, the authors acknowledge that such group classifications (e.g., religious affiliation, no religious affiliation, etc.) would be simplistic and unsophisticated given the variation within each group. 


\section{Conclusion}

Results demonstrate that majority of participants were concerned about potential coercion and abusive practices once EAS is legalized. These attitudes were further shaped by religious faith. Given the nature of the sampling, these results may not reflect the broader New Zealand populations' attitudes, beliefs, and experiences. Nevertheless, study results add to existing quantitative research and form a significant historical context regarding legislative changes. These results may provide valuable information that can inform lawmakers, health professionals, lawyers, advocates, and the broader public of older adults' concerns as New Zealand moves to implement the EOLC Act in 2021. It may also inform future generations of people who may face the prospect of EAS across ages and impairment groups.

Funding This work was supported by the University of Auckland PBRF Grant Ref 71604.

Data availability Due to the nature of this research, participants of this study did not agree for their data to be shared publicly, so supporting data are not available.

\section{Declarations}

Conflict of interest No conflicts of interest to declare.

Ethical Approval The study received approval from the University of Auckland Human Participants Ethics Committee (Ref 024560).

\section{References}

Aarts, S., Patel, K. V., Garcia, M. E., Van den Akker, M., Verhey, F. R., Metsemakers, J. F. M., Van Boxtel, M. P., Gudnason, V., Jonsdottir, M. K., Siggeirsdottir, K., Jonsson, P. V., Harris, T. B., \& Launer, L. J. (2015). Co-Presence of multi-morbidity and disability with frailty: An examination of heterogeneity in the frail older population. The Journal of Frailty \& Aging, 4(3), 131-138. https:// doi.org/10.14283/jfa.2015.45

ACT (N.Z.). (2015, Dec 8). Seymour lodges assisted dying bill (Press Release) ACT party. https://web. archive.org/web/20151208154237/http://www.act.org.nz/posts/seymour-lodges-assisted-dying-bill

Arber, S., Vandrevala, T., Daly, T., \& Hampson, S. (2008). Understanding gender differences in older people's attitudes towards life-prolonging medical technologies. Journal of Aging Studies, 22(4), 366-375. https://doi.org/10.1016/j.jaging.2008.05.009

Attell, B. (2020). Changing attitudes toward euthanasia and suicide for terminally ill persons, 1977 to 2016: An age-period-cohort analysis. Omega-Journal of Death and Dying, 80(3), 355-379. https:// doi.org/10.1177/0030222817729612

Boyd, M., Connolly, M., Kerse, N., Foster, S., von Randow, M., Lay-Yee, R., . . Walters-Puttick, S. (2009). Changes in Aged Care Residents' Characteristics and Dependency in Auckland 1988 to 2008. Findings from OPAL 10/9/8 Older Persons' Ability Level Census. Auckland New Zealand: University of Auckland. https://researchspace.auckland.ac.nz/docs/uoa-docs/rights.htm

Broad, J., Gott, M., Kim, H., Boyd, M., Chen, H., \& Connolly, M. (2013). Where do people die? An international comparison of the percentage of deaths occurring in hospital and residential aged care settings in 45 populations, using published and available statistics. International Journal of Public Health, 58(2), 257-267. https://doi.org/10.1007/s00038-012-0394-5 
Bulmer, M., Böhnke, J., \& Lewis, G. (2017). Predicting moral sentiment towards physician-assisted suicide: The role of religion, conservatism, authoritarianism, and Big Five personality. Personality and Individual Differences, 105, 244-251. https://doi.org/10.1016/j.paid.2016.09.034

Burdette, A., Hill, T., \& Moulton, B. (2005). Religion and attitudes toward physician-assisted suicide and terminal palliative care. Journal for the Scientific Study of Religion, 44(1), 79-93. https://doi.org/10. 1111/j.1468-5906.2005.00266.x

Canham, S. (2009). The interaction of masculinity and control and its impact on the experience of suffering for an older man. Journal of Aging Studies, 23(2), 90-96. https://doi.org/10.1016/j.jaging.2008. 12.003

Carter, G. L., Clover, K. A., Parkinson, L., Rainbird, K., Kerridge, I., Ravenscroft, P., Cavenagh, J., \& McPhee, J. (2007). Mental health and other clinical correlates of euthanasia attitudes in an Australian outpatient cancer population. Psycho-Oncology, 16, 295-303. https://doi.org/10.1002/pon.1058

Castelli Dransart, D., Lapierre, S., Erlangsen, A., Canetto, S., Heisel, M., Draper, B., Linder, R., Richard-Devantoy, R., Cheung, G., Scocco, P., Gusmao, R., De Leo, D., Inoue, K., De Techterman, V., Fiske, A., Hong, J., Landry, M., Lepage, A., \& Marcoux, I, Na, P. J., Neufeld, E., Ummel, D., Winslov, J.-H., Wong, C., Wu, J., \& Wyart, M. (2019). A systematic review of older adults' request for or attitude toward euthanasia or assisted suicide. Aging \& Mental Health, 25(3), 420-430. https:// doi.org/10.1080/13607863.2019.1697201

Cohen, J., Van Landeghem, P., Carpentier, N., \& Deliens, L. (2014). Public acceptance of euthanasia in Europe: A survey study in 47 countries. International Journal of Public Health, 59(1), 143-156. https://doi.org/10.1007/s00038-013-0461-6

Colmar Brunton. (2008). Voluntary Euthanasia Society of New Zealand. Wellington, New Zealand: Colmar Brunton. https://www.odt.co.nz/news/national/most-support-voluntary-euthanasia-survey

Cooke, H. (2019, November 19). M.P.s vote in favour of End of Life Choice Bill at final reading. Stuff. https://www.stuff.co.nz/national/politics/beehive-live/117384206/mps-vote-on-final-readi ng-of-end-of-life-choice-bill

Crothers, C. (2020). Survey (and other social research) data related to the forthcoming referenda on Euthanasia and Cannabis. Auckland University of Technology. https://thepolicyobservatory.aut.ac. nz/_data/assets/pdf_file/0010/396397/Referendums-survey-for-website.pdf

Curran, T. (1997). Effects of aging on implicit sequence learning: Accounting for sequence structure and explicit knowledge. Psychological Research Psychologische Forschung, 60(1), 24-41. https://doi. org/10.1007/BF00419678

Dixon, N. (1998). On the difference between physician-assisted suicide and active Euthanasia. Hastings Center Report, 28(5), 25-29. https://doi.org/10.2307/3528229

Dobrowolska, B., Jędrzejkiewicz, B., Pilewska-Kozak, A., Zarzycka, D., Ślusarska, B., Deluga, A., Kościołek, A., \& Palese, A. (2019). Age discrimination in healthcare institutions perceived by seniors and students. Nursing Ethics, 26(2), 443-459. https://doi.org/10.1177/0969733017718392

Downar, J., Goldman, R., Pinto, R., Englesakis, M., \& Adhikari, N. (2017). The "surprise question" for predicting death in seriously ill patients: A systematic review and meta-analysis. Canadian Medical Association Journal, 189(13), E484-E493. https://doi.org/10.1503/cmaj.160775

Espino, D., Macias, R., Wood, R., Becho, J., Talamantes, M., Finley, M., Hernandez, A., \& Martinez, R. (2010). Physician-assisted suicide attitudes of older Mexican-American and non-Hispanic white adults: Does ethnicity make a difference? Journal of the American Geriatrics Society, 58(7), 13701375. https://doi.org/10.1111/j.1532-5415.2010.02910.x

Etikan, I., Musa, S. A., \& Alkassim, R. S. (2016). Comparison of convenience sampling and purposive sampling. American Journal of Theoretical and Applied Statistics, 5(1), 1-4. https://doi.org/10. 11648/j.ajtas.20160501.11

Fortuin, N., Schilderman, J., \& Venbrux, E. (2020). Determining the end of life: A qualitative study of religion and euthanasia among older Dutch adults. Mortality, 25(2), 167-184. https://doi.org/10. $1080 / 13576275.2019 .1584165$

Frommelt, K. H. M. (1991). The effects of death education on nurses' attitudes toward caring for terminally ill persons and their families. American Journal of Hospice and Palliative Medicine, 8(5), 37-43. https://doi.org/10.1177/104990919100800509

Gale, C., \& Barak, Y. (2020). Euthanasia, medically assisted dying or assisted suicide: Time for psychiatrists to say no. Australasian Psychiatry, 28(2), 160-163. https://doi.org/10.1177/1039856219 878645

Gendall, P. (2002). Massey survey shows support for euthanasia. Massey University. https://www.scoop. co.nz/stories/PO1003/S00389.htm 
Gendall, P. (2009). Massey survey shows support for euthanasia. Massey University http://www.massey. ac.nz/massey/about-massey/news/article.cfm?mnarticle=euthanasia-support-dependent-on-circu mstances-29-03-2010.

George, R., Finlay, I., \& Jeffrey, D. (2005). Legalized euthanasia will violate the rights of vulnerable patients. British Medical Journal, 331(7518), 684-685. https://doi.org/10.1136/bmj.331.7518.684

Golden, M., \& Zoanni, T. (2010). Killing us softly: The dangers of legalizing assisted suicide. Disability and Health Journal, 3(1), 16-30. https://doi.org/10.1016/j.dhjo.2009.08.006

Gomes, J., Cohen, J., Deliens, L., \& Higginson, I. (2011). International trends in circumstances of death and dying amongst older people. In M. Gott, \& C. Ingleton (Eds.), Living with ageing and dying: Palliative and end of life care for older people. Oxford University Press. https://doi.org/10.1108/ ijhcqa.2011.06224gaa.014

Güell, E., Ramos, A., Zertuche, T., \& Pascual, A. (2015). Verbalized desire for death or euthanasia in advanced cancer patients receiving palliative care. Palliative \& Supportive Care, 13(2), 295. https:// doi.org/10.1017/S1478951514000121

Gunzelmann, T., Hinz, A., \& Brähler, E. (2006). Subjective health in older people. GMS Psycho-Social Medicine, 3, 1-10.

Hammond-Thrasher, F. (2020). Medical assistance in dying: A gendered issue in Canada? Spectrum, 6, 2-8. https://doi.org/10.29173/spectrum93

Hendry, M., Pasterfield, D., Lewis, R., Carter, B., Hodgson, D., \& Wilkinson, C. (2013). Why do we want the right to die? A systematic review of the international literature on the views of patients, carers, and the public on assisted dying. Palliative Medicine, 27(1), 13-26. https://doi.org/10.1177/02692 16312463623

Hilário, A. (2015). Making sense of a changed physical body: Why gender matters at the end of life. Journal of Aging Studies, 33, 58-66. https://doi.org/10.1016/j.jaging.2015.03.001

Horizon Research Limited. (2012). New Zealanders' views on end of life choices. Horizon Research Auckland, New Zealand. https://www.horizonpoll.co.nz/attachments/docs/horizon-research-end-oflife-choices-survey--1.pdf

Inouye, S. K. (2021). Creating an anti-ageist healthcare system to improve care for our current and future selves. Nature Aging, 1(2), 150-152. https://doi.org/10.1038/s43587-020-00004-4

Jaye, C., Lomax-Sawyers, I., Young, J., \& Egan, R. (2021). The people speak: Social media on euthanasia/ assisted dying. Medical Humanities, 47(1), 47-55. https://doi.org/10.1136/medhum-2018-011565

Jecker, N. (1991). Age-based rationing and women. Journal of the American Medical Association, 266(21), 3012-3015. https://doi.org/10.1001/jama.1991.03470210080037

Kane, R., \& Kane, R. (2005). Ageism in healthcare and long-term care. Generations, 29(3), 49-54.

Karches, K. E., Chung, G. S., Arora, V., Meltzer, D. O., \& Curlin, F. A. (2012). Religiosity, spirituality, and end-of-life planning: A single-site survey of medical inpatients. Journal of Pain and Symptom Management, 44(6), 843-851.

King, K., Dow, B., Keogh, L., Feldman, P., Milner, A., Pierce, D., Chenhall, R., \& Schlichthorst, M. (2020). "Is Life Worth Living?": The role of masculinity in the way men aged over 80 talk about living, dying, and suicide. American Journal of Men's Health, 14(5), 1-14. https://doi.org/10.1177/ 1557988320966540

Koenig, H. G., Wildman-Hanlon, D., \& Schmader, K. (1996). Attitudes of elderly patients and their families toward physician-assisted suicide. Archives of Internal Medicine, 156(19), 2240-2248. https:// doi.org/10.1001/archinte.1996.00440180104013

Kouwenhoven, P., Raijmakers, N., van Delden, J., Rietjens, J., Schermer, M., van Thiel, G., Trappenburg, M., van de Vathorst, S., van der Vegt, B., Vezzoni, C., Weyers, H., van Tol, D., van der Heide, A. (2013). Opinions of health care professionals and the public after eight years of euthanasia legislation in the Netherlands: a mixed methods approach. Palliative Medicine, 27(3), 273-280.

Lamers, C., \& Williams, R. (2016). Older people's discourses about euthanasia and assisted suicide: A Foucauldian exploration. The Gerontologist, 56(6), 1072-1081. https://doi.org/10.1093/geront/ gnv102

Lee, C., Duck, I., \& Sibley, C. (2017). Demographic and psychological correlates of New Zealanders' support for euthanasia. New Zealand Medical Journal, 130(1448), 9-17.

Luzon, G. (2019). The practice of euthanasia and assisted suicide meets the concept of legalization. Criminal Law and Philosophy, 13(2), 329-345.

Malpas, P., Wilson, M., Rae, N., \& Johnson, M. (2014). Why do older people oppose physician-assisted dying? A qualitative study. Palliative Medicine, 28(4), 353-359. https://doi.org/10.1177/02692 16313511284 
Médecins Sans Frontières (Doctors Without Borders). (2020). Left behind in the times of COVID-19. Médecins Sans Frontières. https://www.doctorswithoutborders.org/what-we-do/news-stories/resea $\mathrm{rch} /$ belgium-left-behind-time-covid-19

Ministry of Health (N.Z.). (2021). End of Life Choice Act. Ministry of Health NZ. https://www.health. govt.nz/our-work/regulation-health-and-disability-system/end-life-choice-act

Morrow, E. (1997). Attitudes of women from vulnerable populations toward physician-assisted death: a qualitative approach. Journal of Clinical Ethics, 8(3), 279-289.

New Zealand Parliament. (2016). How a bill becomes a law. N.Z. Parliament. https://www.parliament.nz/ en/visit-and-learn/how-parliament-works/how-laws-are-made/how-a-bill-becomes-law/

NHS. (2020). Euthanasia and Assisted Suicide. National Health Service. 2017. https://www.nhs.uk/condi tions/euthanasia-and-assisted-suicide/

Panek, P., Hayslip, B., Jr., \& Pruett, J. (2014). How do you know you're old? Gender differences in cues triggering the experience of personal aging. Educational Gerontology, 40(3), 157-171. https://doi. org/10.1080/03601277.2013.802183

Puchalski, C. (2010). Religion, medicine, and spirituality: what we know, what we don't know, and what we do. Asian Pacific Journal of Cancer Prevention, 11(Suppl 1), 45-49.

Radbruch, L., Leget, C., Bahr, P., Muller-Busch, C., Ellershaw, J., de Conno, F. Vanden Berghe, P., \& Board Members of the EAPC. (2016). Euthanasia and physician-assisted suicide: A white paper from the European Association for Palliative Care. Palliative Medicine, 30,104-116. https://doi.org/ $10.1177 / 0269216315616524$

Sabriseilabi, S., \& Williams, J. (2020). Dimensions of religion and attitudes toward euthanasia. Death Studies. https://doi.org/10.1080/07481187.2020.1800863

Smith, J., Braunack-Mayer, A., Wittert, G., \& Warin, M. (2007). "I've been independent for so damn long!": Independence, masculinity, and aging in a help-seeking context. Journal of Aging Studies, 21(4), 325-335. https://doi.org/10.1016/j.jaging.2007.05.004

Statistics New Zealand. (2018). Census of Population and Dwellings. Statistics N.Z. http://datainfoplus. stats.govt.nz/Item/nz.govt.stats/ca28210f-3fd6-415c-a162-ecc07b4a28b0?_ga=2.249487360.62261 950.1609878529-57970878.1609878529\#/nz.govt.stats/ca28210f-3fd6-415c-a162-ecc07b4a28b0/ 43

Steck, N., Egger, M., \& Zwahlen, M. (2016). Assisted and unassisted suicide in men and women: Longitudinal study of the Swiss population. The British Journal of Psychiatry, 208(5), 484-490. https:// doi.org/10.1192/bjp.bp.114.160416

Steck, N., Junker, C., Maessen, M., Reisch, T., Zwahlen, M., Egger, M., \& Cohort, S. N. (2014). Suicide assisted by right-to-die associations: A population-based cohort study. International Journal of Epidemiology, 43(2), 614-622. https://doi.org/10.1093/ije/dyu010

Steck, N., Junker, C., \& Zwahlen, M. (2018). Increase in assisted suicide in Switzerland: Did the socioeconomic predictors change? Results from the Swiss National Cohort. British Medical Journal Open, 8(4), 1-11. https://doi.org/10.1136/bmjopen-2017-020992

Televantos, A., Talias, M., Charalambous, M., \& Soteriades, E. (2013). Attitudes towards euthanasia in severely ill and dementia patients and cremation in Cyprus: A population-based survey. BioMed Central Public Health, 13(1), 1-7. https://doi.org/10.1186/1471-2458-13-878

Tesoriero, P. (2019). The End of Life Choice Bill doesn't protect against coercion. Human Rights Commission. https://www.hrc.co.nz/news/end-life-choice-bill-doesnt-protect-against-coercion-paulatesoriero-disability-rights-commissioner/

Twenge, J., Carter, N., \& Campbell, W. (2015). Time period, generational, and age differences in tolerance for controversial beliefs and lifestyles in the United States, 1972-2012. Social Forces, 94(1), 379-399. https://doi.org/10.1093/sf/sov050

Vilpert, S., Borrat-Besson, C., Borasio, G., \& Maurer, J. (2020). Associations of end-of-life preferences and trust in institutions with public support for assisted suicide evidence from nationally representative survey data of older adults in Switzerland. PLOS ONE, 15(4), e0234954. https://doi.org/10. 1371/journal.pone.0232109

Waterfield, J. (2018). Convenience sampling. In B. B. Frey (Ed.) The SAGE encyclopedia of educational research, measurement, and evaluation (pp. 1-4) Sage. https://doi.org/10.4135/9781506326139. $\mathrm{n} 155$

Wehrle, M. (2020). Becoming old. The gendered body and the experience of aging. In M. Schweda, M. Coors, \& C. Bozzaro (Eds.), Aging and human nature: perspectives from philosophical, theological, and historical anthropology (pp. 75-95). Springer. https://doi.org/10.25285/ 2078-1938-2020-12-2-224-227 
Wright, A., \& Shaw, J. (2019). The spectrum of end of life care: An argument for access to medical assistance in dying for vulnerable populations. Medicine, Health Care, and Philosophy, 22(2), 211-219. https://doi.org/10.1007/s11019-018-9860-z

Wyman, M. F., Shiovitz-Ezra, S., \& Bengel, J. (2018). Ageism in the health care system: Providers, patients, and systems. In L. Ayalon \& C. Tesch-Römer (Eds.) Contemporary perspectives on ageism (pp. 193-212). Springer. https://doi.org/10.1007/978-3-319-73820-8

Young, J., Egan, R., Walker, S., Graham-DeMello, A., \& Jackson, C. (2019). The euthanasia debate: Synthesising the evidence on New Zealander's attitudes. Kōtuitui: New Zealand Journal of Social Sciences Online, 14(1), 1-21. https://doi.org/10.1080/1177083X.2018.1532915

Publisher's Note Springer Nature remains neutral with regard to jurisdictional claims in published maps and institutional affiliations. 